\title{
Impact of Brand Equity, Advertisement and Hedonic Consumption Tendencies on Cognitive Dissonance: A Mediation Study
}

\author{
Allah Wasaya ${ }^{1}$, Bilal Khan ${ }^{1}$, Muhammad Shafee ${ }^{1} \&$ Mirza Sajid Mahmood ${ }^{1}$ \\ ${ }^{1}$ Department of Management Sciences, National University of Modern Languages, Multan, Pakistan \\ Correspondence: Allah Wasaya, Department of Management Science, National University of Modern Languages, \\ Multan, Pakistan. Tel: 92-301-757-7761. E-mail: wasaya061@gmail.com
}

$\begin{array}{ll}\text { Received: February 13, } 2016 & \text { Accepted: April 12, } 2016 \quad \text { Online Published: May 24, } 2016 \\ \text { doi:10.5539/ijms.v8n3p154 } & \text { URL: http://dx.doi.org/10.5539/ijms.v8n3p154 }\end{array}$

\begin{abstract}
Current study puts light on the role of brand equity, hedonic consumption tendencies, and advertisement on cognitive dissonance. Impulse Buying plays the role of a mediator in the study. Purpose of this study is to examine how brand equity, hedonic consumptions, and advertisement affect cognitive dissonance of the customers. Analyses of a sample of 370 customers, drawn from different outlets of famous fashion clothes in Multan city, revealed attention-grabbing findings. A mediation analysis was conducted through regression analysis in the study. Hedonic consumption tendencies and advertisement were found significant in predicting cognitive dissonance while brand equity was found having an insignificant relation with cognitive dissonance where impulse buying found significant in predicting cognitive dissonance being having positive relation. Further to this, impact of brand equity, advertisement and hedonic consumption tendencies found directly related to impulse purchase. Product category wise examination of current model adds new directions and findings in the future. Prior studies on purchase intentions have mainly focused on simple models at any given time. However, researchers increasingly argue that a complex representation may give better understanding of customers' purchase intentions. To the best of the authors' knowledge, this study is one of the first empirical studies to address a complex structure of the proposed variables.
\end{abstract}

Keywords: advertisement, brand equity, cognitive dissonance, hedonic consumption tendencies, impulse buying

\section{Introduction}

Brand equity is positive image about a brand in the mind of a customer (Kim \& Kim, 2005). It can be said that Brand equity is an expression usually used in the marketing field, which defines the value of having a popular brand name. It has been observed that the owner of a well-known brand name can produce more profits from products with that brand name than the products, which have a less known name. Similarly, Doyle (1992) finds that consumers perceive that a product with a distinguished name is better than products with less known names. Some marketers say brands are the most important assets a company holds as brand equity has the ability to increase the financial or total value of a brand to the brand (Barth, Clement, Foster, \& Kasznik, 1998).

Advertisement is a paid form of communication by the use of many communication mediums to influence the customer for buying the product (Kotler \& Zaltman, 1971). Generally, the purpose is to inspire consumer behavior in accordance to the commercial offering, even though political and ideological advertising is too common (Duncan \& Moriarty, 1998). In Latin language, advertise means, "to turn toward". The purpose of the advertising can also be to create trust (faith) in the mind of the shareholders as well as in the mind of employees that the company is strong, capable and prompt to the success (Smith, 2007).

Consumption of products based primarily on the desire to experience pleasure and happiness (Alba \& Williams, 2013). Hedonic consumption in general may refer to as the traits of individuals to engage in activities resulting in pleasure and relief in tension (Hoch \& Loewenstein, 1991). Literature documents show a very strong relationship between shopping experience and hedonic tendencies.

An impulse purchase or impulse buying is an unplanned decision to buy a product or service, made just before a purchase (Stern, 1962). Customers who usually try to make such purchases are termed as impulse purchasers or impulse buyers. Many researches show that emotions and feelings play a very important role in buying process, elicited by having a glance of the product or upon exposure to a well hewed promotional message (Park, Kim, \& 
Forney, 2006). Companies and retailers try to exploit these impulses, which are snarled to the basic want of instant satisfaction.

As a view of psychology, individuals feel faced anxiety or uneasiness because of the cognitive dissonance (McGregor, Zanna, Holmes \& Spencer, 2001). Conflicts do exist in the beliefs, ideas, or values, which are usually motivated by some new information because individuals at the same time hold two or more different beliefs, ideas, or values (Pajares, 1992). Leon Festinger has introduced the word cognitive dissonance in 1957, one of his theories tells about, how a man tries to control or concentrate on his internal consistency. When someone feels uneasiness, he/she tries to reduce the reasons behind the uneasiness or try to eliminate the source of uncomforting (Allyn \& Festinger, 1961).

This study helps to identify some important factors, which affect impulse buying and cognitive dissonance. Many of the studies have explained the effect of impulse buying on cognitive dissonance before. None of the studies has mentioned any relationship between brand equity, Advertisement and hedonic consumption with the cognitive dissonance in a mediation study. This study contributes in knowing how brand equity and advertisement, hedonic consumption tendencies via a mediating variable (impulse buying) affect cognitive dissonance.

\section{Literature Review}

\subsection{Brand Equity}

Brand equity is an important concept for current organizations, and it has been studied for many years. In marketing practices, such as differentiation and service quality, create customer-based brand equity (CBBE) - it is a concept which tells that consumers react more positively towards branded products as compared to non-branded products (Aaker, 1991). Keller (1993) defines CBBE as the differential effect about different brands in the mind of the customers.

Brand equity is value-enhancing element for any company. It adds value and gets preference in the product or service. As earlier studies tells that CBBE increases loyalty toward a company and its products (Keller, 1993; Moradi \& Zarei, 2012) also, it helps to generate greater margins in profits and gives brand-extension opportunities and much more (Aaker 1991; Allaway et al., 2011; Buil et al., 2008).

Consumer-based brand equity is usually measured from different angles as awareness, brand association, perceived quality, and brand loyalty. Aaker (1996, p. 10) defines brand awareness as the strength by which customers can recall a specific brand. Similarly, it can be said that brand awareness is a customer's ability to recognize a brand (Aaker, 1991; Pappu et al., 2005). Further, Yoo et al. (2000) assess that brand awareness and brand association can be combined in a single term as association.

$\mathrm{H1}$ : Brand equity influences cognitive dissonance.

\subsection{Advertisement}

Advertising is a paid form of communication (promotion) about a product or service to persuade customers (Richards et al., 2002). Advertising is in use since a long for the promotion of goods and services. It is an influential and most effective way of communication of information regarding a product. For proper communication, advertising needs great focus.

Advertising attracts customer's attention but it is not the case always, as Fitzgerald (1998) tells that $90 \%$ of his advertising is wasted and he does not know of what part $90 \%$ is comprised. Whether advertising gets customer's attention due to quality of product or advertising itself or because of any other reason, it still needs to be studied. Crux of the discussion is that, advertising has a positive impact on the mind of the customers (Krishnamurthy, 2001; Martin et al., 2003).

H2: Advertisement influences cognitive dissonance.

\subsection{Hedonic Consumption Tendencies}

Hedonism can be defined as the principle that pleasure is the highest value in a unique or attractive life-style zealous to pleasure seeking (The Chambers Dictionary, 1993). Delight, joy, elation, ecstasy and enjoyment are different aspects of hedonism (Andrew, 2008). Pleasure seeking is a sensual need of the customers, so it attracts customer's attention with higher hedonic (Hirschman \& Holbrook, 1982). On the other hand, hedonism may have an adverse impact on the humanity. In addition, action-based model of dissonance tells that people attempt to bring equilibrium between conflicting beliefs as aversive and consonance (Jones, 1999). This may result in some actions which are harmful for humanity but for hedonic purpose. Hedonic consumption also has negative impact on well-being, as it is for only customer's satisfaction in his or her own way (Zhong \& Mitchell, 2010). 
H3: Hedonic consumption influences cognitive dissonance.

\subsection{Impulse Buying}

Impulse buying has both cognitive as well as affective elements in it. Its cognitive aspect is concerned with just planning and affective with situational factors, which cause impulse buying (Verplanken \& Herabadi, 2001). Mostly consumers do impulse buying as it gives pleasure and reduces burden of choosing from a bundle of products (Hauseman, 2000). It has been observed that, impulse buying has adverse impacts on personality trait as well-being and is concerned only with pleasure (Silvera et al., 2008).

On the other hand, impulse buying reduces stress and tension in shopping. As George and Yaoyuneyong (2010) find that impulse buying is actually a strategy to reduce distress and anxiety and give pleasure. Further (Rook and Hoch, 1985) assess that impulse buying is all about pleasure seeking purpose. As many consumers have told that, they feel better in doing impulsive purchase (Rook, 1987).

Impulse buying is an important element from retailing point of view also. As some of the retailers consider impulse buying as a most important factor which has an impacts on their business; different types of strategies have been made to deal with the impulse buying tendencies as product placement and point-of-purchase advertising displays are some of the strategies implied to deal with it (Wood, 1998).

H4a: Impulse buying influences cognitive dissonance.

H4b: Impulse buying mediates the relationship between brand equity, advertisement, hedonic consumption tendencies and cognitive dissonance.

\subsection{Cognitive Dissonance}

Leon Festinger defined cognitive dissonance first time where he differentiated among opposite belief, which can be a cause of cognitive (Festinger, 1957). Festinger (1957) add that people having faced with negative cognition try to take actions to reduce its negative impact and attain equilibrium or better state. The negative dissonance due to mismatch in expected and actual performance of the products changes customer attitude towards that product in future (Jones et al., 2009).

Intensity of cognitive dissonance depends on two factors as personality traits of the customers and variables, which cause dissonance (Jones et al., 2009). A lot of stress has been laid in knowing factors behind cognitive dissonance and few as desire for structured life, fear of invalidity, well-being traits and negative state of mind have been tested and found related with cognitive dissonance (Thompson et al., 1989; Beck et al., 1979; Diener et al., 1985; Ryff \& Keyes, 1995).

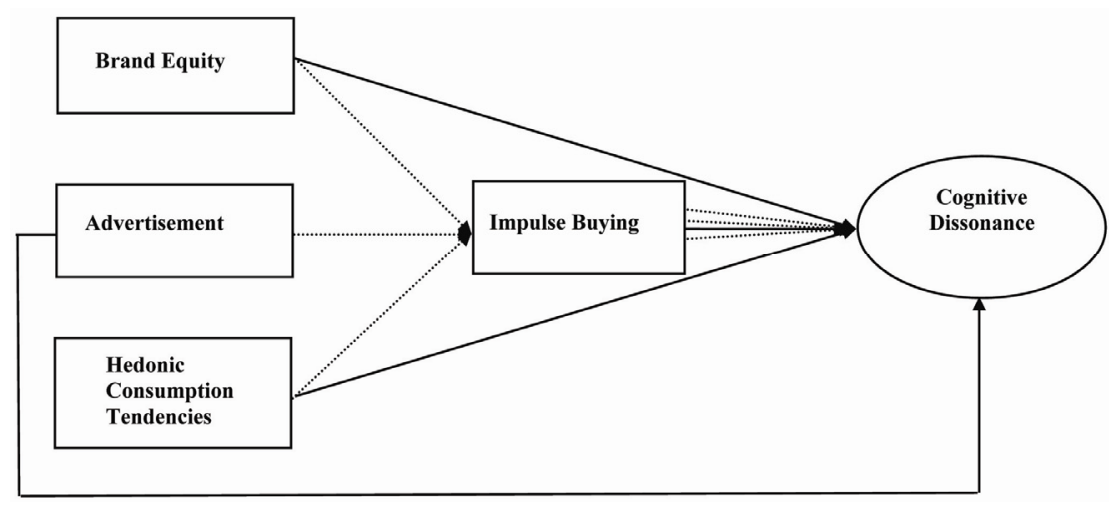

Figure 1. Conceptual framework

\subsection{Research Question}

1) What is the impact of brand equity on cognitive dissonance?

2) What is the impact of advertisement on cognitive dissonance?

3) What is the impact of hedonic consumption tendencies on cognitive dissonance?

4) What is the impact of mediating role of impulse buying on the relationship between brand equity, advertisement, hedonic consumption tendencies and cognitive dissonance?

The research objective is to identify the effect of brand equity, advertisement and hedonic consumption on 
impulse buying and cognitive dissonance attached with various fashion-oriented clothes' purchase by customers where Impulse buying plays a mediating role in the study.

\section{Method}

A sample of 370 customers from different fashion oriented clothes outlets of Multan city were approached directly, during various occasions, for data collection purpose. Customers were given a questionnaire to answer the questions pertaining to cognitive dissonance, hedonic consumption tendency, advertisement and brand equity.

\subsection{Sample Characteristics}

Out of 370 customers taken as a sample, 350 useful responses were chosen for analysis. Twenty questionnaires were excluded due to missing values and non-serious response. Average age of the respondents appeared out to be 27 years. Out of 370 respondents 265 were females that constitutes $77 \%$ of the sample and 85 were males that constitute $23 \%$ of sample.

\subsection{Measurement Instrument}

A self-administered questionnaire was used for the data collection purpose. Brand Equity scale was adopted from Yoo, Donthu, and Lee (2000). Advertisement Scale adopted from Henthorne, LaTour \& Nataraajan (1993). Impulse buying tendency scale was adopted from Rook and Fisher (1995), cognitive dissonance from Gyoungho Lee \& Jaesool Kwon (2003) and hedonic consumption tendency scale was adopted from Babine et al. (1994).

\subsection{Reliability of Scale}

The reliability of scale for various variables and dimensions, used in this study, is shown in Table1. Over all internal reliability of the instrument is good with alpha value of 0.895 . Individual analysis of reliability for various variables also showed satisfactory results having impulse buying scale 0.597 , advertisement scale 0.825 , brand equity scale 0.516 , hedonic consumption tendencies scale 0.754 and cognitive dissonance 0.684 .

Table 1. Overview of scales' reliability

\begin{tabular}{ll}
\hline Variable / Scale & Cronbach Alpha $(\alpha)$ \\
\hline & 0.895 \\
Advertisement & 0.825 \\
Brand Equity & 0.516 \\
Hedonic Consumption Tendencies & 0.754 \\
Impulse Buying & 0.597 \\
Cognitive Dissonance & 0.684 \\
\hline
\end{tabular}

\section{Results}

In this section, the results obtained from the analysis of data are presented and findings along with its possible implications are discussed. Multiple Regressions are conceded having brand equity, advertisement, impulse buying and hedonic consumption tendencies as independent variables and cognitive dissonance as dependent variable. The results are summarized in Tables 2, 2a and $2 \mathrm{~b}$.

\subsection{Statistics and Data Analysis}

4.1.1 Advertisement, Brand Equity, Hedonic Consumption Tendencies and Impulse Buying-Cognitive Dissonance Relationship

Model summary reveals that brand equity, advertisement, impulse buying and hedonic consumption tendencies predict $35 \%$ variation in cognitive dissonance. ANOVA table entails that prediction is statistically significant at $\mathrm{p}<0.05$.

However, hedonic consumption tendencies, advertisement and impulse buying are significant in predicting cognitive dissonance having t-values 5.223, 3.345 and 3.875 respectively at $p<0.05$ whereas, brand equity is insignificant in prediction having t-value 1.793 at $\mathrm{p}>0.05$ i.e. 0.074 (Table $2 \mathrm{~b}$ ). Beta coefficients presented in table $2 \mathrm{~b}$ show that brand equity, advertisement, hedonic consumption tendencies and impulse buying have direct relationship with cognitive dissonance with $\beta$ values $0.098,0.096,0.289$ and 0.235 respectively.

Statistical results shown in Table $2 \mathrm{~b}$ approve hypotheses H1, H2, H3 and H4. 
Table 2. Regression analysis summary

\begin{tabular}{lllll} 
Model Summary & \multicolumn{3}{l}{} \\
\hline Mode & $\mathrm{R}$ & R Square & Adjusted R Square & Std. Error of the Estimate \\
\hline 1 & .591 & .350 & .342 & .41054 \\
\hline
\end{tabular}

a. Predictors: (Constant), $H C T, B E, A D, I B$

b. Dependent Variable: $C D$

Table 2a. ANOVA analysis

\begin{tabular}{lllllll} 
ANOVA $^{\mathrm{b}}$ & & & & \\
Model & & Sum of Squares & df & Mean Square & F & Sig. \\
\hline 1 & Regression & 31.263 & 4 & 7.816 & 46.374 & $.000^{\mathrm{a}}$ \\
& Residual & 58.147 & 345 & .169 & & \\
& Total & 89.410 & 349 & & & \\
\cline { 2 - 6 }
\end{tabular}

a. Predictors: (Constant), $H C T, B E, A D, I B$

b. Dependent Variable: $C D$

Table 2b. Coefficients in regression analysis

\begin{tabular}{|c|c|c|c|c|c|}
\hline \multirow[b]{2}{*}{ Model } & \multicolumn{2}{|c|}{ Unstandardized Coefficients } & \multicolumn{2}{|c|}{ Standardized Coefficients } & \multirow[b]{2}{*}{ Sig. } \\
\hline & $\mathrm{B}$ & Std. Error & Beta & $\mathrm{t}$ & \\
\hline 1 (Constant) & .896 & .122 & & 7.3 & .000 \\
\hline $\mathrm{AD}$ & .078 & .046 & .098 & 1.6 & .014 \\
\hline $\mathrm{BE}$ & .073 & .041 & .096 & 1.7 & .074 \\
\hline HCT & .292 & .056 & .289 & 5.2 & .000 \\
\hline IB & .246 & .063 & .235 & 3.8 & .000 \\
\hline
\end{tabular}

a. Dependent Variable: $C D$

\subsubsection{Brand Equity, Advertisement and Hedonic Consumption Tendency-IB Relationship}

Multiple Regressions was again proceeded to describe impact of brand equity, advertisement and hedonic consumption tendency on impulse buying tendency. The results are summarized in Tables 3, 3a and $3 \mathrm{~b}$.

Model summary disclose that brand equity, advertisement and hedonic consumption tendencies estimate $48.5 \%$ variation in impulse buying (Table 3). ANOVA table empirically verifies that prediction is statistically significant at $\mathrm{p}<0.05$ (Table $3 \mathrm{a}$ ).

Brand equity, advertisement and hedonic consumption tendency are significant in predicting impulse buying having t-values $4.722,7.507$ and 5.733 respectively at $p<0.05$. Beta coefficients illustrate that brand equity, advertisement and hedonic consumption tendency have direct relationship with impulse buying tendency with $\beta$ values $0.218,0.362$ and 0.269 respectively (Table $3 b$ ). Statistical results presented in Table $3 b$ approve hypothesis $\mathrm{H} 1 \mathrm{~b}, \mathrm{H} 2 \mathrm{~b}$ and $\mathrm{H} 3 \mathrm{~b}$. Figure 2 gives an estimated model of this study after getting statistical results.

Table 3. Regression analysis summary

\begin{tabular}{|c|c|c|c|c|}
\hline Mode & $\mathrm{R}$ & R Square & Adjusted R Square & Std. Error of the Estimate \\
\hline 1 & .697 & .485 & .481 & .34801 \\
\hline
\end{tabular}


Table3a. ANOVA analysis

\begin{tabular}{lllllll}
\multicolumn{2}{ll}{ ANOVA $^{\mathrm{b}}$} \\
\multicolumn{2}{l}{ Model } & Sum of Squares & df & Mean Square & F & Sig. \\
\hline 1 & Regression & 39.514 & 3 & 13.171 & 108.755 & $.000^{\mathrm{a}}$ \\
& Residual & 41.904 & 346 & .121 & & \\
& Total & 81.418 & 349 & & & \\
\end{tabular}

a. Predictors: (Constant), $H C T, B E, A D$

b. Dependent Variable: IB

Table 3b. Coefficients in regression analysis

\begin{tabular}{|c|c|c|c|c|c|}
\hline \multirow[b]{2}{*}{ Model } & \multicolumn{2}{|c|}{ Unstandardized Coefficients } & \multicolumn{2}{|c|}{ Standardized Coefficients } & \multirow[b]{2}{*}{ Sig. } \\
\hline & $\mathrm{B}$ & Std. Error & Beta & $\mathrm{t}$ & \\
\hline 1 (Constant) & .728 & .096 & & 7.605 & .000 \\
\hline $\mathrm{AD}$ & .273 & .036 & .362 & 7.507 & .000 \\
\hline $\mathrm{BE}$ & .158 & .033 & .218 & 4.722 & .000 \\
\hline HCT & .260 & .045 & .269 & 5.733 & .000 \\
\hline
\end{tabular}

a. Dependent Variable: IB

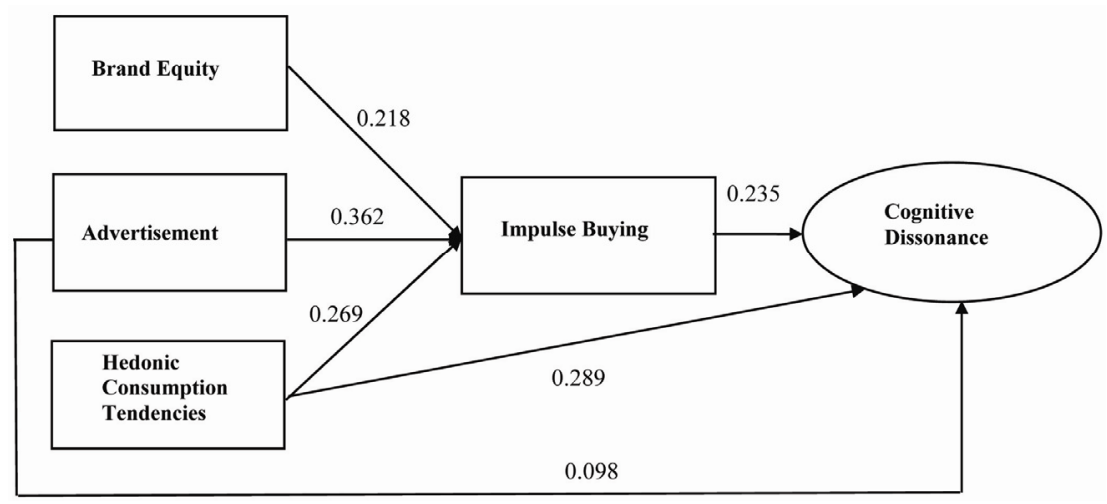

Figure 2. Estimated model

\section{Limitations of the Study and Directions for Future Research}

Even though choice of customers from different fashion clothes brand outlets as a sample establishes very important portion of target population and shows stimulating information in this study, still verification of the model on many other sample categories remains an interesting path to be discovered. Exploring influence of the given model on any other specific product category may unveil novel dimensions. Level of cognitions may vary with variations in demographic profiles of the customers. This study is comprised of fashion clothes products only and conducted in Multan, Pakistan.

\section{References}

Aaker, D. A. (1991). Management brand equity. New York.

Aaker, D. A., \& Joachimsthaler, E. (2000). Brand leadership: The next level of the brand revolution. New York.

Alba, J. W., \& Williams, E. F. (2013). Pleasure principles: A review of research on hedonic consumption. Journal of Consumer Psychology, 23(1), 2-18. http://dx.doi.org/10.1016/j.jcps.2012.07.003

Allaway, A. W., Huddleston, P., Whipple, J., \& Ellinger, A. E. (2011). Customer-based brand equity, equity drivers, and customer loyalty in the supermarket industry. Journal of Product \& Brand Management, 20(3), 190-204. http://dx.doi.org/10.1108/13563281111141642

Allyn, J., \& Festinger, L. (1961). The effectiveness of unanticipated persuasive communications. The Journal of 
Abnormal and Social Psychology, 62(1), 35. http://dx.doi.org/10.1037/h0048493

Barth, M. E., Clement, M. B., Foster, G., \& Kasznik, R. (1998). Brand values and capital market valuation. Review of Accounting Studies, 3(1-2), 41-68. http://dx.doi.org/10.1023/A:1009620132177

Beck, A. T., \& Rush, A. J., Shaw, B. F., \& Emery, G. (1979). The Cognitive Therapy of Depression (pp. 171-186).

Buil, I., Chernatony, L. De \& Martínez, E. (2008). Across-national validation of the consumer-based brand equity scale. Journal of Product \& Brand Management, 17(6), 384-392. http://dx.doi.org/10.1108/10610420810904121

Diener, E. D., Emmons, R. A., Larsen, R. J., \& Griffin, S. (1985). The satisfaction with life scale. Journal of Personality Assessment, 49(1), 71-75. http://dx.doi.org/10.1207/s15327752jpa4901_13

Doyle, P. (1992). Building successful brands: the strategic options. Journal of Product \& Brand Management, l(4), 5-20. http://dx.doi.org/10.1108/10610429210036889

Duncan, T., \& Moriarty, S. E. (1998). A communication-based marketing model for managing relationships. The Journal of Marketing, 1-13. http://dx.doi.org/10.2307/1252157

Festinger, L. (1957). A Theory of Cognitive Dissonance. Stanford, CA: Stanford University Press.

George, B. P., \& Yaoyuneyong, G. (2010). Impulse buying and cognitive dissonance: a study conducted among the spring break student shoppers. Young Consumers, 11(4), 291-306. http://dx.doi.org/10.1108/17473611011093925

Harmon-Jones, E. E., \& Mills, J. E. (1999). Cognitive dissonance: Progress on a pivotal theory in social psychology. In Scientific Conferences Program, 1997, U Texas, Arlington, TX, US; American Psychological Association. http://dx.doi.org/10.1037/10318-000

Harmon-Jones, E., Amodio, D. M., \& Harmon-Jones, C. (2009). Action-Based Model of Dissonance: A Review, Integration, and Expansion of Conceptions of Cognitive Conflict. Advances in experimental social psychology, 41, 119-166. http://dx.doi.org/10.1016/S0065-2601(08)00403-6

Hasan, U., \& Nasreen, R. (2012). An Indepth Analysis of Variables Affecting Post Purchase Cognitive Dissonance. Global Journal of Management and Business Research, 12(20).

Hausman, A. (2000). A multi-method investigation of consumer motivations in impulse buying behavior. Journal of Consumer Marketing, 17(5), 403-426. http://dx.doi.org/10.1108/07363760010341045

Hirschman, E. C., \& Holbrook, M. B. (1982). Hedonic consumption: emerging concepts, methods and propositions. The Journal of Marketing, 92-101. http://dx.doi.org/10.2307/1251707

Hoch, S. J., \& Loewenstein, G. F. (1991). Time-inconsistent preferences and consumer self-control. Journal of Consumer Research, 492-507. http://dx.doi.org/10.1086/208573

Keller, K. L. (1993). Conceptualizing, measuring, and managing customer-based brand equity. The Journal of Marketing, 1-22. http://dx.doi.org/10.2307/1252054

Kim, H. B., \& Kim, W. G. (2005). The relationship between brand equity and firms' performance in luxury hotels and chain restaurants. Tourism Management, 26(4), 549-560. http://dx.doi.org/10.1016/j.tourman.2004.03.010

Koller, M., \& Salzberger, T. (2007). Cognitive dissonance as a relevant construct throughout the decision-making and consumption process-an empirical investigation related to a package tour. Journal of Customer Behaviour, 6(3), 217-227. http://dx.doi.org/10.1362/147539207X251022

Kotler, P., \& Zaltman, G. (1971). Social marketing: an approach to planned social change. The Journal of Marketing, 3-12. http://dx.doi.org/10.2307/1249783

Krishnamurthy, S. (2001). A comprehensive analysis of permission marketing. Journal of Computer-Mediated Communication, 6(2). http://dx.doi.org/10.1111/j.1083-6101.2001.tb00119.x

Li, H., Edwards, S. M., \& Lee, J. H. (2002). Measuring the intrusiveness of advertisements: Scale development and validation. Journal of Advertising, 31(2), 37-47. http://dx.doi.org/10.1080/00913367.2002.10673665

Mackay, M. M. (2001). Evaluation of brand equity measures: Further empirical results. Journal of Product \& Brand Management, 10(1), 38-51. http://dx.doi.org/10.1108/10610420110382812

Martin, B. A. S., Durme, J. V., Raulas, M., \& Merisavo, M. (2003). Email advertising: exploratory insights from Finland. Journal of Advertising Research, 43(3), 293-300. http://dx.doi.org/10.1017/s0021849903030265 
McGregor, I., Zanna, M. P., Holmes, J. G., \& Spencer, S. J. (2001). Compensatory conviction in the face of personal uncertainty: going to extremes and being one self. Journal of Personality and Social Psychology, 80(3), 472. http://dx.doi.org/10.1037/0022-3514.80.3.472

Moradi, H., \& Zarei, A. (2012). Creating consumer-based brand equity for young Iranian consumers via country of origin sub-components effects. Asia Pacific Journal of Marketing and Logistics, 24(3), 394-413. http://dx.doi.org/10.1108/13555851211237885

Netemeyer, R. G., Krishnan, B., Pullig, C., Wang, G., Yagci, M., Dean, D., ... \& Wirth, F. (2004). Developing and validating measures of facets of customer-based brand equity. Journal of Business Research, 57(2), 209-224. http://dx.doi.org/10.1016/S0148-2963(01)00303-4

Oliver, R. L. (1997). Satisfaction: A behavioral perspective on the customer. New York.

Pajares, M. F. (1992). Teachers' beliefs and educational research: Cleaning up a messy construct. Review of Educational Research, 62(3), 307-332. http://dx.doi.org/10.1080/13603116.2015.1090489

Pappu, R., Quester, P. G., \& Cooksey, R. W. (2005). Consumer-based brand equity: improving the measurement-empirical evidence. Journal of Product \& Brand Management, 14(3), 143-154. http://dx.doi.org/10.1108/10610420510601012

Park, E. J., Kim, E. Y., \& Forney, J. C. (2006). A structural model of fashion-oriented impulse buying behavior. Journal of Fashion Marketing and Management, 10(4), 433-446. http://dx.doi.org/10.1108/13612020610701965

Raggio, R. D., \& Leone, R. P. (2007). The theoretical separation of brand equity and brand value: Managerial implications for strategic planning. Journal of Brand Management, 14(5), 380-395. http://dx.doi.org/10.1057/palgrave.bm.2550078

Richards, J. I., \& Curran, C. M. (2002). Oracles on "advertising": Searching for a definition. Journal of Advertising, 31(2), 63-77. http://dx.doi.org/10.1080/00913367.2002.10673667

Rook, D. W. (1987). The buying impulse. Journal of Consumer Research, 14(2), 189-199. http://dx.doi.org/10.1086/209105

Rook, D. W., \& Hoch, S. J. (1985). Consuming impulses. Advances in Consumer Research, 12(1), 23-27.

Ryff, C. D., \& Keyes, L. M., (1995). The structure of psychological well-being revisited. Journal of Personality and Social Psychology, 69, 719-727. http://dx.doi.org/10.1037/0022-3514.69.4.719

Silvera, D. H., Lavack, A. M., \& Kropp, F. (2008). Impulse buying: the role of affect, social influence, and subjective wellbeing. Journal of Consumer Marketing, 25(1), 23-33. http://dx.doi.org/10.1108/07363760810845381

Smith, A. D. (2007). Making the case for the competitive advantage of corporate social responsibility. Business Strategy Series, 8(3), 186-195. http://dx.doi.org/10.1108/17515630710684187

Stern, H. (1962). The significance of impulse buying today. The Journal of Marketing, 59-62. http://dx.doi.org/10.2307/1248439

Thompson, M. M., Naccarato, M. E., \& Parker, K. E. (1989). Assessing cognitive need: The development of the personal need for structure and personal fear of invalidity scales.

Verplanken, B., \& Herabadi, A. (2001). Individual differences in impulse buying tendency: Feeling and no thinking. European Journal of personality, 15(S1), S71-S83. http://dx.doi.org/10.1002/per.423

Wood, M. (1998). Socio-economic status, delay of gratification, and impulse buying. Journal of Economic Psychology, 19(3), 295-320. http://dx.doi.org/10.1016/S0167-4870(98)00009-9

Yoo, B., \& Donthu, N. (2001). Developing and validating multidimensional consumer-based brand equity scale. Journal of Business Research, 52(1), 1-14. http://dx.doi.org/10.1016/S0148-2963(99)00098-3

Yoo, B., Donthu, N., \& Lee, S. (2000). An examination of selected marketing mix elements and brand equity. Journal of the Academy of Marketing Science, 28(2), 195-211. http://dx.doi.org/10.1177/0092070300282002

Zhong, J. Y., \& Mitchell, V. W. (2010). A mechanism model of the effect of hedonic product consumption on well-being. Journal of Consumer Psychology, 20(2), 152-162. http://dx.doi.org/10.1016/j.jcps.2010.01.001 


\section{Copyrights}

Copyright for this article is retained by the author(s), with first publication rights granted to the journal.

This is an open-access article distributed under the terms and conditions of the Creative Commons Attribution license (http://creativecommons.org/licenses/by/3.0/). 